\title{
Online Teaching Self-Efficacy - How English Teachers Feel During the Covid-19 Pandemic
}

\author{
Shzh-chen Nancy Lee ${ }^{1}$, Chie Ogawa ${ }^{2}$ \\ ${ }^{1}$ Osaka University, Japan \\ ${ }^{2}$ Kyoto Sangyo University, Japan
}

Abstract: The transition from traditional face-to-face to online teaching during the Covid-19 pandemic happened so rapidly that most teachers started teaching without enough training, preparation, and knowledge of online teaching. In order to better understand this current teaching paradigm, the present research examined how English teachers perceive their own ability to teach online. It investigated English teachers' self-efficacy to teach online by surveying 138 EFL university teachers in Japan. A survey with 29 Likert-scale and two open-ended questions was developed to examine four latent constructs of online English teaching self-efficacy: technology, pedagogy, communicative language teaching, and self-management. Results of the survey found that English teachers were highly self-efficacious toward teaching online. They were most self-efficacious toward the usage of technology, followed by pedagogy, communicative language teaching (CLT), and least efficacious toward self-management when teaching online. Teachers had high self-efficacy for using different online platforms, organizing group work activities, and conducting formative assessments for evaluation. On the other hand, teachers had lowest self-efficacy for maintaining the balance between research and teaching activities. This paper concludes with some pedagogical implications for English teachers when teaching online.

Keywords: Communicative language teaching; Covid-19 pandemic; Online teaching; Pedagogy; Self-efficacy; Self-management; Technology.

\section{INTRODUCTION}

The Covid-19 pandemic has changed the lives of many teachers and students, one of the biggest changes in education being the transition from face-toface to online teaching. The transition to online for many teachers happened so quickly that many started teaching without enough training, preparation in developing teachers' ability to teach online. Developing the ability to effectively teach online and knowing how to teach online therefore became the primary focus for many practitioners and researchers. However, while teacher development for online teaching is important, knowing how teachers are perceiving their abilities to teach online is also equally important. Self-efficacy is teachers' belief in their ability to effectively handle tasks, obligations, and challenges related to their teaching activities (Tschannen-Moran \& Woolfolk Hoy, 2001). It is directly and indirectly related to the performance and wellness of teachers as well as the performance and wellness of their students (Chacon, 2005). Therefore, highly selfefficacious teachers tend to create more positive relationships with students, 
conduct more effective student-centered classrooms, and cope more effectively with problematic behaviors in classrooms (Zee \& Koomen, 2016). While teachers' self-efficacy has been widely researched in the past, their self-efficacy to teach online has only received little attention. Especially in the field of language learning and teaching, how teachers perceive their ability to teach online has almost been overlooked in recent literature.

This study aims to examine teachers' self-efficacy to teach online by examining how university English teachers in Japan perceive their own ability to work online by looking at their self-efficacy for technology usage, pedagogy, communicative language teaching (CLT), and self-management. It examined these four latent constructs of online self-efficacy using a 29-item six-point Likert scale survey with short answer questions. The survey was distributed to university English teachers (both native and non-native teachers) in Japan through snowball sampling via Facebook conference pages, conference mailing lists and emails. It is hoped that this study will be able to examine English teachers' voices about teaching online and to suggest some implications for future teaching. The literature review section begins with a board review of teacher self-efficacy before reviewing self-efficacy for English teachers than on the limited literature of online teaching self-efficacy for language teachers. The method section includes a description of survey development and delivery followed by a brief discussion of preliminary analysis. The results and discussion section includes a description and interpretation of Likert-scale item results supplemented with comments made by the participants. The conclusion section concludes the overall scope of the study with implications, limitations, and final remarks.

\section{LITERATURE REVIEW}

Self-efficacy was introduced to the field of second language learning and teaching to describe self-perceived capabilities to attain designated goals (Bandura, 1978). However, similar terms have long been used to describe language learners' perception of their own performance, such as self-confidence (Gardner, Tremblay \& Masgoret, 1997), self-perception, and self-rating (MacIntyre, Noels \& Clément, 1997). Self-efficacy is different from these terms because it is task specific and also specific to the context of the learning situation (Taipjutorus, Hansen, \& Brown, 2012). Self-efficacious learners feel competent in their ability to accomplish these tasks (Mills, 2014). Self-efficacy has direct and indirect influences on language learners (Piniel \& Csizér, 2013) such as increasing their motivation, engagement, persistence, effort, and decreasing anxiety (Bandura, 1988). Self-efficacy therefore directly and indirectly determines learning success of learners (Mills, Pajares \& Herron, 2006). Learners have higher self-efficacy if they could relate the target task to similar successfully completed previous experiences, observe peers successfully completing similar tasks and if they could have little anxiety toward the task (Bandura, 1997). These sources of self-efficacy often form a cyclic relationship with self-efficacy in which positive past experiences lead to higher self-efficacy, which leads to more positive experiences and subsequently lead to higher selfefficacy again. 
For teachers, self-efficacy is the belief in their own ability to effectively handle tasks, obligations, and challenges related to teaching activities (TschannenMoran \& Woolfolk Hoy, 2001). Teachers who perceive themselves to be capable tend to create more positive relationships with students and are better at coping with problems in classrooms (Zee \& Koonmen, 2016), which positively impact their students' learning outcomes (Chacon, 2005). Previous studies on the self-efficacy of English teachers found that teachers with different demographic backgrounds (e.g., teaching experiences, faculty development, pedagogical capabilities, and English proficiency levels) have different self-efficacy levels to teach English (Atay, 2007; Choi \& Lee, 2016). In addition, English teachers have different levels of selfefficacy for different elements of teaching (Chacon, 2005). For example, it was found in the same study that teachers have the highest self-efficacy for instructional strategies as teachers perceived themselves to be more capable of designing instruction than to motivate students to learn English.

For self-efficacy toward technology usage, several studies have examined teachers' perception in their ability integrate technology into instruction using the framework of Technological Pedagogical Content Knowledge (TPCK) (e.g., Ferdig, 2006; Koehler \& Mishra 2005; Mishra \& Koehler, 2006). These studies suggested that technological knowledge is needed on top of knowledge of the subject matter and instruction strategies. Furthermore, teachers need knowledge about technologies and the capabilities to use them to utilize their advantages in teaching (Mishra \& Koehler, 2006). Besides educational technology, online Web instruction created new teaching and learning opportunities with new challenges (Lee \& Tsai, 2010; Wallace, 2004). One of the most significant advancements in online teaching might be the improvement in interactive communication that offers new ways of acquiring instructional information and learning resources, such as synchronous, asynchronous, autonomous, and collaborative modes of teaching and learning (Jain \& Getis, 2003; Neo, 2003). Jain and Getis (2003) suggested that the Internet becomes an innovative communication tool in education as it can be used in both distance-learning environments or classroom settings. Therefore, Lee and Tsai (2010) added the Web component and created a modified framework called Technological Pedagogical Content Knowledge-Web (TPCK-W) for understanding the self-efficacy of primary and secondary school teachers in Taiwan. Lee and Tsai's study found that teachers have low self-efficacy toward using the Web for teaching. In addition, teachers with more Web experience have higher levels of selfefficacy.

Online teaching self-efficacy for language teachers was researched by Lin and Zheng (2015). It surveyed 33 language teachers in the United States about the types of activities/tasks teachers engaged in their teaching practice, how they feel about their own instructional and technological efficacies. The study further interviewed six language teachers on their online teaching experiences who commented that online teaching is more demanding than face-to-face teaching because it requires teachers to take up both content-related and non-content-related teaching roles such as providing instructions as well as performing managerial and social duties. It was found that more time is needed to prepare for online lessons because more specific and structured planning are required (Lin \& Zheng, 2015). 
The interviewees also commented that online teaching requires more preparation time because group and pair work activities that can be conducted easily face-toface need to be designed using specific online technologies when teaching online. Lin and Zheng (2015) also found that teachers feel synchronous classes are more intensive compared to face-to-face mode classes as they cover more content in the same class time when teaching online. Therefore, students are also required to do more preview beforehand to get ready for online classes as more class content is covered in the same amount of time. Finally, interviews from the study found that the lack of physical presence impose challenges on some of the language teachers as body language and eye contact are needed when teaching languages. The lack of physical presence requires language teachers to spend more time with instruction explanation, delivering content, and providing corrections for students, for example, with correcting students' pronunciation since they cannot see students' mouth shapes. Finally, the study found that many teachers feel they need to respond more rapidly to students when teaching online because of lack of physical presence. Teachers commented that they try to respond more quickly to their students because they are concerned students might feel more isolated and frustrated.

\section{RESEARCH METHOD}

In order to examine English teachers' self-efficacy toward online teaching, a survey instrument was developed and distributed. The participants were 138 English teachers (native speaking and non-native speaking) who teach in Japanese universities. Most of the participants $(n=118)$ commented that it was their first semester teaching online when completing this survey while a small number of participants had a few years of online teaching experience. Participants who responded to this survey were teaching a variety of English courses including language skill development courses (i.e., listening, speaking, writing, and reading), communicative language teaching (CLT), task-based or content-based courses.

A survey was developed in English consisting of six background demographic items (gender, age, educational background, teaching experience, online teaching experience, and professional development), 29 Likert-scale questions, and two open-ended questions (See Appendix). Six-point was used for the Likert scale items $(1=$ Strongly Disagree, $2=$ Disagree, $3=$ Slightly disagree, $4=$ Slightly agree, $5=$ Agree, $6=$ Strongly agree) (Nemoto \& Beglar, 2014). The Likert scale items were developed to examine four latent constructs toward online teaching self-efficacy by referring to a previous study (Lin \& Zheng, 2015) and informal interviews with university English teachers. There were ten pedagogy selfefficacy items, seven technology items, six communicative language teaching (CLT) items, and six self-management items. The two open-ended questions were included so that participants could elaborate their choice of Likert scale responses and make general comments on their perception of teaching online. Although the four constructs consisted of their own individual items, the constructs also overlap (See Figure 1) because items of one construct cannot be completely independent from the items of other constructs, for example, teachers who perceive themselves to have technological knowledge integrate this knowledge into their pedagogical instruction and vice versa. In this survey, all items were developed into "can do" statements because self-efficacy expresses perceived capability (Bandura, 2006). 


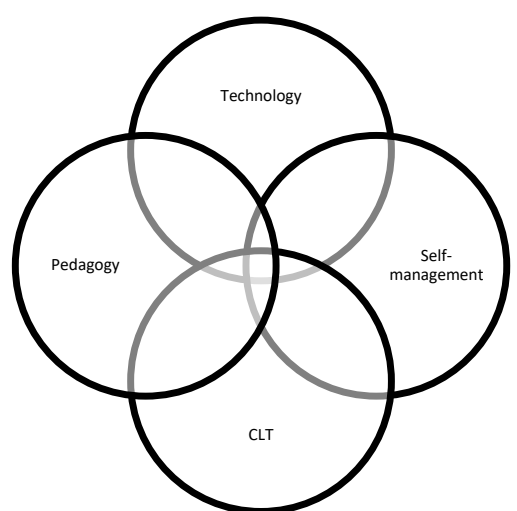

Figure 1. Overlap between four constructs (Adapted from Lee \& Tsai, 2010)

The survey was proofread and piloted by five English teachers before it was distributed. This anonymous survey was distributed through snowball sampling to Japanese university English teachers using Google forms where it was circulated on conference mailing lists, Facebook pages, and emails. The survey was open access and remained online for one month in June, 2020. Rasch analysis was conducted using WINSTEPS version 3.64.2 (Linacre \& Wright, 2007) on the raw data collected for each of the four latent constructs to examine their item fit to the Rasch model as well as construct dimensionality, reliability, and to produce interval measures. A total of six items (items 1, 2, 10, 11, 12, and 29 in Appendix) were deleted because they did not fit the minimum model criteria. Normality and multicollinearity of the four constructs were checked and met after deletion of these six items.

\section{FINDINGS AND DISCUSSION}

Participants expressed positive responses toward the usage of technology, pedagogy, CLT, and self-management when teaching online (See Table 1). These results suggest that the Japanese university English teachers in this study were selfefficacious to teach online. This positive result supports previous studies that found teachers to be self-efficacious of their teaching (Atay, 2007; Choi \& Lee, 2016). In particular, participants of this study had highest self-efficacy toward the usage of technology $(M=4.53)$ which was substantially higher than the other constructs. However, this positive finding also refutes previous studies that found a lack of technological self-efficacy in using online technology for teaching (e.g., Dawley, Rice \& Hinck, 2010; Mishra \& Koehler, 2006). Lin and Zheng (2015) also found a lack of technological self-efficacy in teachers as that they felt they do not know enough about online technology (Dawley et al., 2010; Mishra \& Koehler, 2006). It can be considered that participants of this study felt positively toward technology self-efficacy because online technology has become more prevalent compared to one decade ago when the above previous studies were conducted. Therefore, more teachers have become more familiar with integrating technology into teaching. It can also be considered that more teachers are more highly self-efficacious about teaching online because those who responded voluntarily to this online survey were ones that are confident about their teaching because they had to complete this questionnaire using their own private time. 
Table 1. Descriptive Statistics of Four Online Teaching Self-Efficacy Constructs

\begin{tabular}{clccc}
\hline No. & & Construct & $\boldsymbol{M}$ & $\boldsymbol{S D}$ \\
\hline 1. & Pedagogy & 4.18 & .81 \\
2. & Technology & 4.53 & .99 \\
3. & CLT & 4.41 & .98 \\
4. & Self-management & 3.50 & 1.17 \\
\hline
\end{tabular}

$N=138,6$-point Likert scale. CLT $=$ communicative language teaching

For technology related items, participants responded most positively to them and all items were above a mean of 4.30 (See Table 2). Item 16, I can use appropriate software (e.g. spreadsheets, electronic portfolios) to manage student performance data, was the highest $(M=4.73)$, followed by item 15 , I can use online technology platforms (e.g. Blackboard, Google Classroom Moodle, MS Teams, Zoom) to conduct evaluations $(M=4.63)$, and item 17 , I can find additional technological tools (e.g. apps, platforms) to support my teaching online $(M=4.56)$. The results suggest that most teachers could be self-efficacious of technology when teaching online, for example one participant commented, "Technology has given me more tools to be a better teacher than an entertainer. Moreover, I can give far better individual feedback on each assignment that I receive." Other participants commented, "I have always been comfortable using Google Drive for personal reasons related to teaching, so it was easy to transition to using them with my students. I have found ways to supplement and ever augment the tasks I did in previous years in the same courses" and "I taught students how to email me at the beginning of the course and receive regular emails from students at all proficiency levels. I can also reply to students through chat messages in Teams at my main university." These comments suggest that teachers were familiar and selfefficacious with using apps when teaching online.

Table 2. Descriptive Statistics of Technology Related Items

\begin{tabular}{c|l|c|c}
\hline No. & \multicolumn{1}{|c|}{ Item } & M & SD \\
\hline & $\begin{array}{l}\text { I can use online technology platforms (e.g. Blackboard, Google } \\
\text { Classroom Moodle, MS Teams, Zoom) to motivate students to } \\
\text { participate }\end{array}$ & 4.37 & 1.05 \\
\hline 13 & $\begin{array}{l}\text { I can use online technology platforms (e.g. Blackboard, Google } \\
\text { Classroom Moodle, MS Teams, Zoom) to mentor students }\end{array}$ & 4.34 & 1.19 \\
\hline 15 & $\begin{array}{l}\text { I can use online technology platforms (e.g. Blackboard, Google } \\
\text { Classroom Moodle, MS Teams, Zoom) to conduct evaluations }\end{array}$ & 4.63 & 1.13 \\
\hline 16 & $\begin{array}{l}\text { I can use appropriate software (e.g. spreadsheets, electronic portfolios) to } \\
\text { manage student performance data }\end{array}$ & 4.73 & 1.41 \\
\hline 17 & $\begin{array}{l}\text { I can find additional technological tools (e.g. apps, platforms) to support } \\
\text { my teaching online }\end{array}$ & 4.56 & 1.32 \\
\hline$N=138$, 6-point Likert scale.
\end{tabular}

For item 13, I can use online technology platforms (e.g. Blackboard, Google Classroom Moodle, MS Teams, Zoom) to motivate students to participate, a combination of $48.5 \%$ of participants responded 6, I strongly agree and 5, I agree (See Figure 2). On the other hand, no participant responded 1, I strongly disagree and only six participants answered 2, I disagree. This result suggests that teachers were highly self-efficacious with using different online technology platforms in

\section{Indonesian TESOL Journal}


their classes. One possible reason for this result is because the integration of technology platforms into teaching is not completely new for some teachers and many of them had some previous experience or were introduced by their universities to platforms such as blackboard or Moodle prior to teaching online. Another possible reason is because this survey was distributed by snowball sampling online so that participants who responded to this survey are considered to be familiar with working online or had some level of confidence with working online.

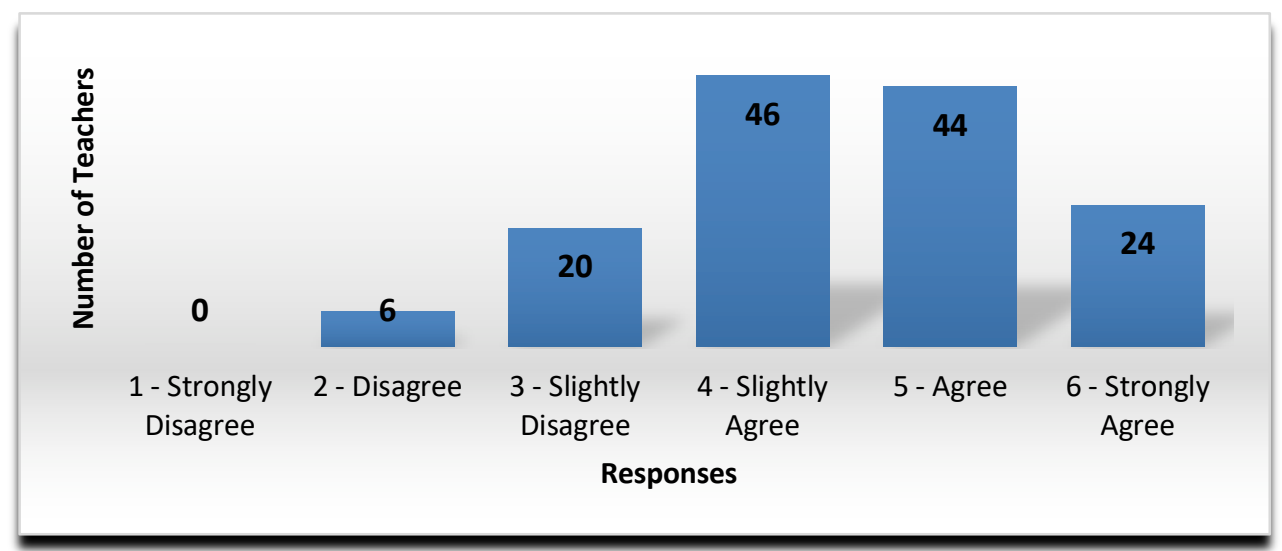

Figure 2. I Can Use Online Technology Platforms (e.g. Blackboard, Google Classroom Moodle, MS Teams, Zoom) to Motivate Students to Participate

For CLT related items, participants responded positively and all items except one were above a mean of 4.30 (See Table 3). Participants responded most positively toward item 20 , I can organize meaning-focused activities online ( $M=$ 4.72), followed by item 23 , I can evaluate task-based learning assessments online $(M=4.41)$, and item 20 , I can give corrective feedback to students online $(M=$ 4.40). The results suggest that most teachers were highly self-efficacious of conducting communicative language teaching online. This positive finding was different from previous study which found teachers who practice communicative language teaching could not teach effectively online due to their physical absence from classrooms (Lin \& Zheng, 2015). Thompson and Woodman (2019) also found Japanese English teachers to have low confidence in offering communicative language teaching classes. Some participants also commented negatively on their ability to teach communicatively online, for example, "I have discovered many roadblocks to teaching language online. One of these being student resistance to communicating and engaging face-to-face online," many participants commented positively. For example one participant positively commented, "Students seemed to study with no major issue via Zoom, using Google Classroom to communicate with me and other classmates, and another participant commented, "I have plenty of tools available to communicate with students online - video conferencing, LMS, email, chat applications." This difference between present study and previous studies might have derived because Thompson and Woodman's (2019) study focused on Japanese high school teachers who were concerned of the level of their L2 proficiency whereas the present study did not include items to elicit participants' perceived L2 proficiency ability. 
Table 3. Descriptive Statistics of CLT Related Items

\begin{tabular}{|c|c|c|c|}
\hline No. & Construct & $M$ & $S D$ \\
\hline 18 & I can organize group work activities online. & 4.38 & 1.23 \\
\hline 19 & I can organize pair work activities online. & 4.16 & 1.38 \\
\hline 20 & $\begin{array}{l}\text { I can organize meaning-focused activities online (i.e. not focusing on } \\
\text { grammar). }\end{array}$ & 4.72 & 1.07 \\
\hline 21 & $\begin{array}{l}\text { I can organize task-based learning activities online (e.g. student group } \\
\text { presentation). }\end{array}$ & 4.37 & 1.32 \\
\hline 22 & $\begin{array}{l}\text { I can give corrective feedback to students online (e.g. correcting } \\
\text { grammar). }\end{array}$ & 4.40 & 1.26 \\
\hline 23 & $\begin{array}{l}\text { I can evaluate task-based learning assessments online (e.g. oral } \\
\text { presentation). }\end{array}$ & 4.41 & 1.28 \\
\hline
\end{tabular}

$N=138$, 6-point Likert scale. CLT $=$ communicative language teaching

Among the positively rated CLT related items, a number of participants commented on the structure of group work when teaching online. For item 18, I can organize group work activities online, $22.5 \%$ of participants responded 6, I strongly agree, and 29\% of participants responded 5, I agree, and 29\% of participants responded 4, I slightly agree (See Figure 3). One participant commented, "Many of the things usually done $\mathrm{f} 2 \mathrm{f}$ can be done to a certain degree online, and some are easier -eg making groups for discussion." Another participant commented, "Technology allows for group interaction and presentations." In addition, most teachers in this study were efficients in organising group work online because teachers of large size classes have already selectively avoided group work. For example, one participant commented, "I can't do Zoom classes with larger groups" and another participant commented, "Checking in and discussing tasks with groups is challenging, even with zoom breakout rooms. However, my class sizes are reasonably small enough (18-25) that I can interact meaningfully with students." It suggests that most teachers were self-efficacious of organizing group work activities while teaching online especially when their groups were not too large.

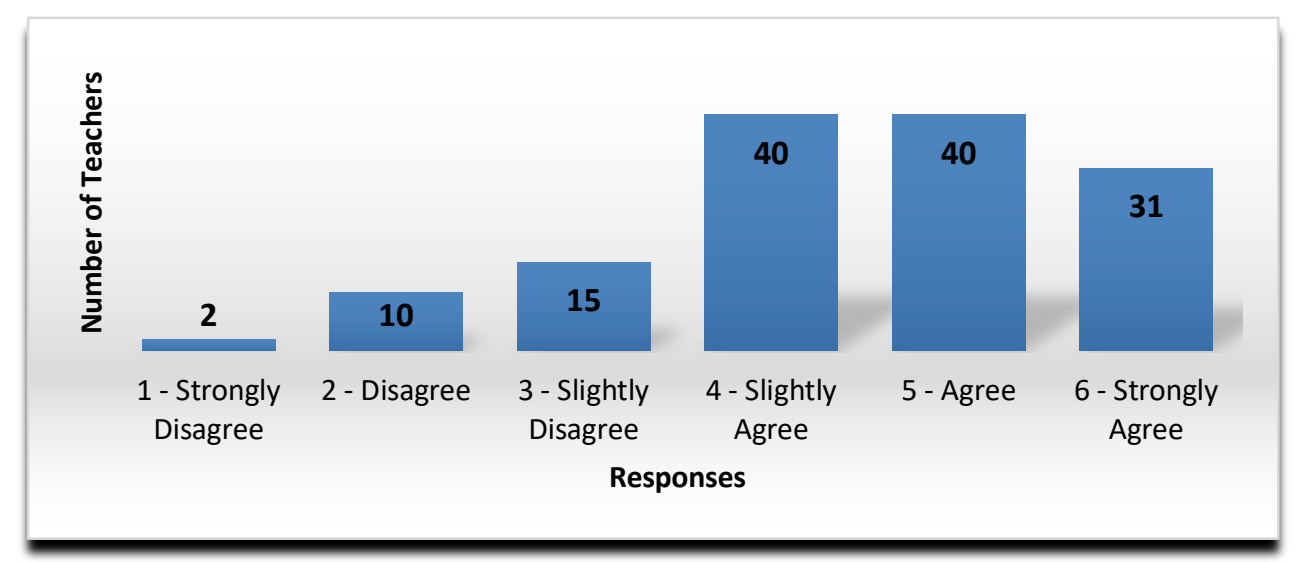

Figure 3. I Can Organize Group Work Activities Online 
For pedagogy related items, participants responded positively to all pedagogy related items where six out of the seven items had a mean of 4.0 and above (see Table 4). The highest rated item was item 9, I can use formative (inprogress) assessments to evaluate student learning online $(M=4.44)$ followed by item 3, I can develop students' language proficiency online $(M=4.41)$. These results suggest that teachers in this study were self-efficacious of their pedagogical ability and this finding supports previous study by Chacon (2005) who found teachers to be confident in their pedagogical instruction. Many participants commented positively in their instruction ability while teaching online, stating online teaching to be not so different from face-to-face teaching. For example, one participant commented, "Not having face-to-face contact is not ideal, but I feel confident I can provide adequate instruction by combining many teaching methods and constantly keeping in touch with my students, Of course, I have more confidence in face-to-face support, but feel that I'm just as capable as anyone else behind the computer and explaining something live to my students."

Participants rated item 4, I can motivate students online who show a low interest in language learning, the lowest $(M=3.48)$. It suggests that a number of teachers were not confident with their ability to motivate students online and this result supports Chacon (2005) who found that while teachers are confident in their pedagogical instruction, they are not confident in their ability to motivate students to learn English. One participant commented, "I think I have conducted my lessons at an adequate level. I wish I could be more creative and use my personality to motivate my students more. For now, I feel like I'm just trying to get by and complete my basic duties as a teacher." Therefore, the survey responses suggest that teachers found online teaching environments to be less conducive to motivating students.

Table 4. Descriptive Statistics of Pedagogy Related Items

\begin{tabular}{c|l|c|c}
\hline No. & \multicolumn{1}{|c|}{ Construct } & \multicolumn{1}{|c}{$\boldsymbol{|}$} & \multicolumn{1}{|c}{$\boldsymbol{|}$} \\
\hline 3 & I can develop students' language proficiency online. & 4.41 & 1.08 \\
\hline 4 & $\begin{array}{l}\text { I can motivate students online who show a low interest in language } \\
\text { learning. }\end{array}$ & 3.48 & 1.27 \\
\hline 5 & I can coordinate students' collaboration online. & 4.24 & 1.24 \\
\hline 6 & I can motivate students online to do their homework. & 4.37 & 1.15 \\
\hline 7 & $\begin{array}{l}\text { I can provide individual instruction to cater for students' individual } \\
\text { needs online. }\end{array}$ & 4.02 & 1.37 \\
\hline 8 & $\begin{array}{l}\text { I can use summative (end-point) assessments to evaluate student learning } \\
\text { online. }\end{array}$ & 4.31 & 1.31 \\
\hline 9 & $\begin{array}{l}\text { I can use formative (in-progress) assessments to evaluate student } \\
\text { learning online. }\end{array}$ & 4.44 & 1.26 \\
\hline
\end{tabular}

$N=138$, 6-point Likert scale.

While participants all responded positively toward pedagogy related items, participants responded mostly positively toward item 9, I can use formative (inprogress) assessments to evaluate student learning online, where $24.5 \%$ of participants responded 6, I strongly agree, 30.2\% of participants responded 5, I agree, and $25.9 \%$ responded 4, I slightly agree (See Figure 4). One participant further commented, "Teaching online is the most efficient use of time and resources in my opinion, and opens up many new possibilities for both mentoring and 
evaluation, that were not possible in a classroom setting." This result suggests that a large number of teachers were confident with doing in-progress evaluations when teaching online. However, there were some teachers who lacked confidence in making formative assessments online. For item 9, three participants responded 1, $I$ strongly disagree, eight participants responded 2, I disagree, and sixteen participants responded 3, I slightly disagree. Evaluating online can be a concern for some teachers especially with the nature of the type of courses they are teaching, for example, one participant commented, "Teaching online has generally not been difficult. However, giving assessments for listening and reading has been difficult. At my university, we are not equipped with a good system to give such types of assessments in a way that can prevent cheating." The results suggest that while most teachers were self-efficacious of doing formative assessments online, some teachers were not due to the type of courses they were teaching and also because they felt they were not sufficiently equipped with the suitable technology.

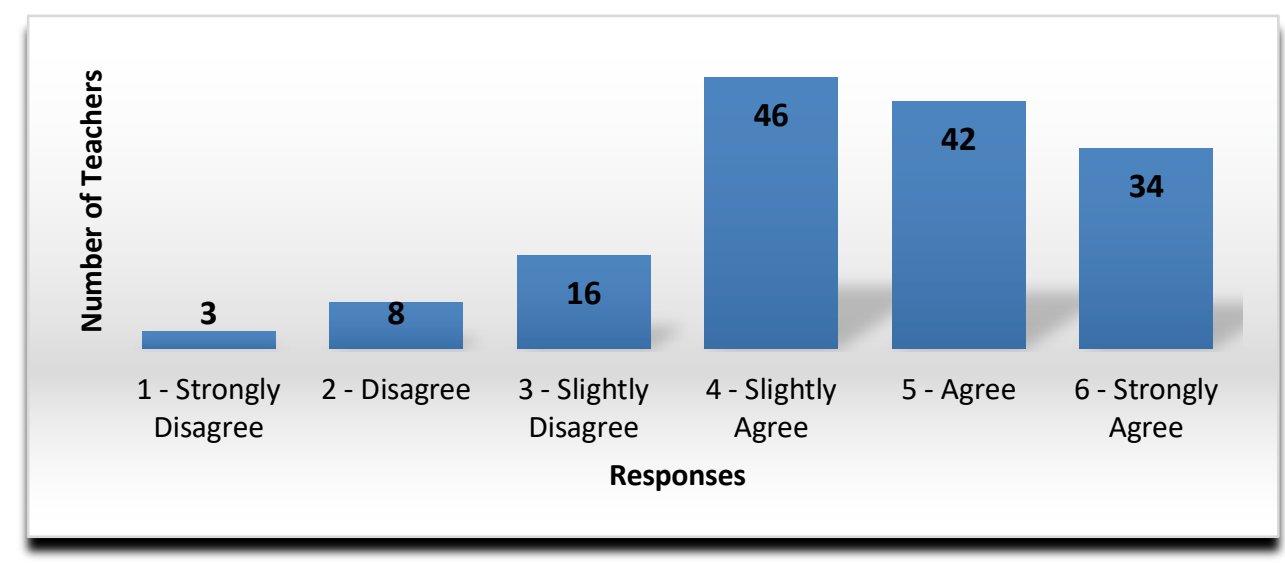

Figure 4. I Can Use Formative Assessments to Evaluate Student Learning Online

For online self-management related items, participants responded least positively with only two items above a mean of 4.0 (See Table 5). The lowest item was item 27, I can balance the demands of teaching and research when teaching online $(M=2.78)$, followed by item, 28, I can balance the demands of teaching and personal life when teaching online $(M=3.08)$, and item 24 , I can manage my workload when teaching online $(M=3.42)$. These results suggest that teachers did not feel self-efficacious toward managing themselves when teaching online. Many participants commented that they were having difficulties due to the lack of time. For example, one participant commented, "The combination of synchronous and asynchronous methods together seems to be just as effective as in classwork, though takes more time to prepare and to assess." Some other participants commented, "I'm still learning what I'm doing. My school provided no support, so my first few weeks were not very successful-and now I'm just running out of time to do all the work. It's very hard on my eyes" and "I have much more workload than ever! I feel I am working 24/7. Too many things to prepare, and too many emails and Slack messages from colleagues and students. I am sacrificing my personal life and health." These results support Lin and Zheng's (2015) finding that teachers feel online synchronous mode classes are more intensive. Teachers felt they were unable to effectively manage themselves because they were overwhelmed by the need to 
answer students more quickly, grade assessments more speedily, and to provide more channels for students to reach out to them (Lin \& Zheng, 2015).

Table 5. Descriptive Statistics of Self-Management Related Items

\begin{tabular}{c|l|c|c}
\hline No. & \multicolumn{1}{|c|}{ Item } & $\boldsymbol{M}$ & $\boldsymbol{S D}$ \\
\hline 24 & I can manage my workload when teaching online. & 3.42 & 1.60 \\
\hline 25 & I can find help when I am having difficulties teaching online. & 4.02 & 1.39 \\
\hline 26 & $\begin{array}{l}\text { I can find teacher development resources to improve my online teaching } \\
\text { ability. }\end{array}$ & 4.27 & 1.25 \\
\hline 27 & $\begin{array}{l}\text { I can balance the demands of teaching and research when teaching } \\
\text { online. }\end{array}$ & 2.78 & 1.59 \\
\hline 28 & $\begin{array}{l}\text { I can balance the demands of teaching and personal life when teaching } \\
\text { online }\end{array}$ & 3.08 & 1.63 \\
\hline$N=138$, 6-point Likert scale. & \multicolumn{2}{l}{}
\end{tabular}

While participants still responded somehow positively to other selfmanagement related items, they responded most negatively toward item 27, I can balance the demands of teaching and research when teaching online, where $31.1 \%$ of participants responded 1, I strongly disagree, $14.1 \%$ of participants responded 2, I disagree, and $21.5 \%$ of participants responded 3, I slightly disagree (See Figure 5). One participant commented, "The amount of time this takes in online classes far exceeds the amount of time it would have taken me otherwise, so I currently have no time for outside research." Another participant commented, "Balancing teaching and research and personal life remains a struggle. I also frequently have to be working at the computer from $8 \mathrm{AM}$ until $8 \mathrm{PM}$ or later, so in some ways being at home yet absent is even harder." These results suggest that teachers were not efficacious about balancing between their teaching and research activities as they simply felt there was not enough time.

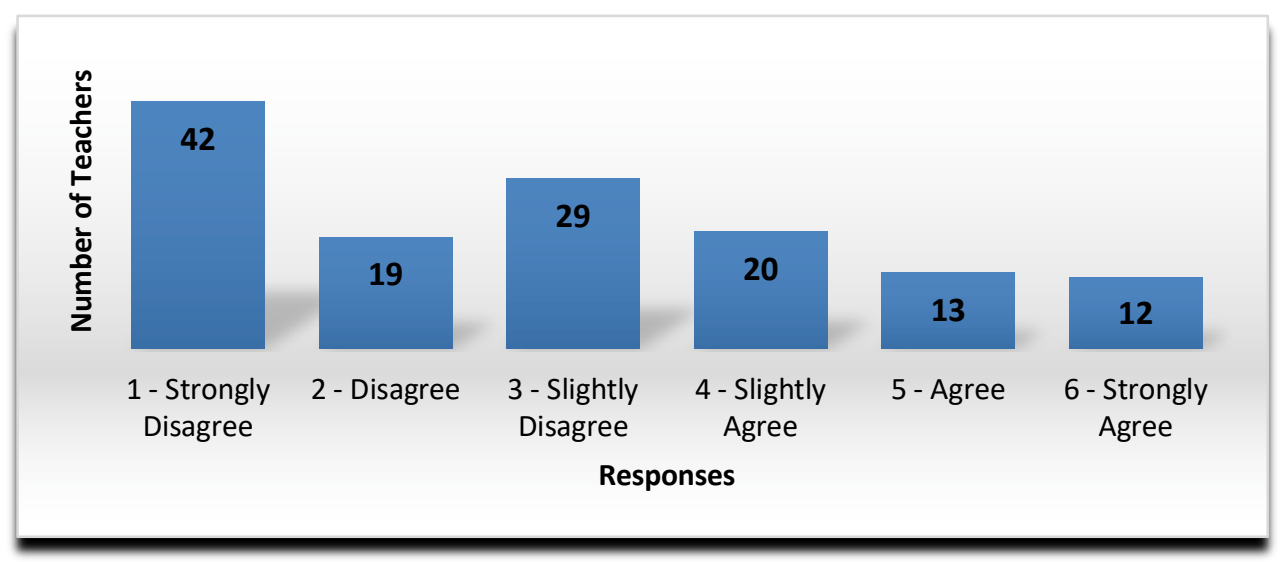

Figure 5. I Can Balance Demands of Teaching and Research When Teaching Online

\section{CONCLUSION}

This research was an attempt to better understand the online teaching paradigm during the pandemic by examining Japanese university English teachers' self-efficacy to teach online through analyzing quantitative and qualitative responses from a survey instrument. It was found that many English teachers at the 
university level were highly self-efficacious toward teaching online. In particular, they were most self-efficacious toward the usage of technology, followed by pedagogy, and communicative language teaching (CLT). For technology, teachers had high self-efficacy for using different online platforms, for CLT, teachers were highly self-efficacious with organizing group work activities, for pedagogy, teachers were highly self-efficacious with using formative assessments for evaluation. On the other hand, teachers had the lowest self-efficacy toward selfmanagement due to the lack of time and many struggled with maintaining the balance between research and teaching activities.

A few implications can be suggested for English language teachers from this research, not only to help teachers with online teaching during the pandemic but to also prepare teachers for future teaching. Teachers need to know how to organize themselves when teaching online including how to make more time for themselves and how to put a stop to work. Teachers need to know that they are not obligated to work 24 hours a day as there are no concrete working hours online. While it is important to satisfy the needs of students, teachers also need to reduce their own stress and frustration level and one of the ways to do so is to set clear work on and off times. Peer support and networking will also help teachers to become more self-efficacious to teach online. One participant commented, "I'm grateful to my coworkers and the community on the Facebook group in which I am active."

There are also limitations in this study because there was not enough time to pilot the survey items before they were given to the participants due to our attempt to distribute the survey to teachers as soon as possible at the earlier stage of the Covid-19 pandemic. The wording and validity of some of the survey items can be questioned. Therefore, the results of the survey items need to be interpreted with caution. The survey was distributed through snowball sampling online so it was possible that only online self-efficacious teachers responded to this survey and thus biased the results. In addition, it was likely that only teachers who are familiar with working online responded to this survey. Therefore, the survey would need to be distributed evenly to teachers who do not practice or practice less online teaching. Finally, although background demographic items were included in the survey, there were not enough participants for demographic group analysis to be conducted according to different gender, age, educational background, teaching experience, online teaching experience, and professional development experience. Therefore, the survey would need to be distributed to a larger sample of participants in order to examine the self-efficacy of teachers of different demographic groups. While this study was not without limitations, we hope that it could add to the limited body of literature on online teaching self-efficacy especially for teachers who teach English as a second or foreign language. Future studies are called to better understand English teachers' online teaching self-efficacy as it is currently an underdeveloped area that needs immediate attention as it is no doubt impacting current and future teaching and learning.

\section{ACKNOWLEDGMENTS}

We would like to thank all teachers who helped with our survey and one female researcher who generously proofread this paper. 


\section{REFERENCES}

Atay, D. (2007). Beginning teacher efficacy and the practicum in an EFL context. Teacher Development, 11(2), 203-219. https://doi.org/10.1080/13664530701414720

Bandura, A. (1978). Self-efficacy: Toward a unifying theory of behavioral change. Advances in Behaviour Research and Therapy, 4(1), 139-161. https://doi.org/10.1016/0146-6402(78)90002-4

Bandura, A. (1988). Self-efficacy conception of anxiety. Anxiety Research, 1(2), 77-98. https://doi.org/10.1080/10615808808248222

Bandura, A. (1997). Self-efficacy: The exercise of control. New York: Freeman.

Bandura, A. (2006). Guide for constructing self-efficacy scales. In F. Pajares \& T. Urdan (Eds.), Self-efficacy beliefs of adolescents (Vol. 5, pp. 307-337). Greenwich, CT: Information Age Publishing.

Chacon, C. T. (2005). Teachers' perceived efficacy among English as a foreign language teachers in middle schools in Venezuela. Teaching and Teacher Education, 21, 257-272. https://doi:10.1016/j.tate.2005.01.001

Choi, E., \& Lee, J. (2016). Investigating the relationship of target language proficiency and self-efficacy among nonnative EFL teachers. System, 58, 49-63. https://doi.org/10.1016/j.system.2016.02.010

Dawley, L., Rice, K., \& Hinck, G. (2010). Going virtual! The status of professional development for K-12 online teachers. Boise State University. Retrieved from https://edtech.boisestate.edu/goingvirtual/goingvirtual3.pdf

Ferdig, R. E. (2006). Assessing technologies for teaching and learning: Understanding the importance of technological pedagogical content knowledge. British Journal of Educational Technology, 37, 749-760. https://doi.org/10.1111/j.1467-8535.2006.00559.x

Gardner, R. C., Tremblay, P. F., \& Masgoret, A. (1997). Towards a full model of second language learning: An empirical investigation, The Modern Language Journal, 31(3), 344-362. https://doi.org/10.1111/j.15404781.1997.tb05495.x

Jain, C., \& Getis, A. (2003). The effectiveness of internet-based instruction: An experiment in physical geography. Journal of Geography in Higher Education, 27, 153-167. https://doi.org/10.1080/03098260305679

Koehler, M. J., \& Mishra, P. (2005). What happens when teachers design educational technology? The development of technological pedagogical content knowledge. Journal of Educational Computing Research, 32(2), 131-152. https://doi.org/10.2190/0EW7-01WB-BKHL-QDYV

Lee, M. H., \& Tsai, C. C. (2010). Exploring teachers' perceived self efficacy and technological pedagogical content knowledge with respect to educational use of the World Wide Web, Instructional Science, 38(1),1-21. https://dog.org/10.1007/s11251-008-9075-4 
Lin, C. H., \& Zheng, B. (2015). Teaching practices and teacher perceptions in online world language courses. Journal of Online Learning Research, 1(3), 275-303.

Linacre, J. M., \& Wright, B. D. (2007). WINSTEPS: Multiple-choice, rating scale, and partial credit Rasch analysis [Computer software]. Chicago, IL: MESA.

MacIntyre, P. D., Noels, K. A., \& Clément, R. (1997). Biases in self-ratings of second language proficiency: The role of language anxiety. Language Learning, 47(2), 265-287. https://doi.org/10.1111/0023-8333.81997008

Mills, N. (2014). Self-efficacy in second language acquisition. In S. Mercer \& M. Williams (Eds.), Multiple perspectives on the self in SLA (pp. 6-19). Bristol, England: Multilingual Matters.

Mills, N., Pajares, F., \& Herron, C. (2006). A reevaluation of the role of anxiety: Self-efficacy, anxiety, and their relation to reading and listening proficiency. Foreign Language Annals, 39(2), 276-294. https://doi.org/10.1111/j.1944-9720.2006.tb02266.x

Mishra, P., \& Koehler, M. J. (2006). Technological pedagogical content knowledge: A framework for teacher knowledge. Teachers College Record, 108(6), 1017-1054. https://doi.org/10.1111/j.1467$\underline{9620.2006 .00684 . x}$

Nemoto, T., \& Beglar, D. (2014). Developing Likert-scale questionnaires. In N. Sonda \& A. Krause (Eds.), JALT2013 Conference Proceedings (pp. 1-8). Tokyo, Japan: JALT.

Neo, M. (2003). Developing a collaborative learning environment using a webbased design. Journal of Computer Assisted Learning, 19, 462-473. https://doi.org/10.1046/j.0266-4909.2003.00050.x

Piniel, K., \& Csizér, K. (2013). L2 motivation, anxiety and self-efficacy: The interrelationship of individual variables in the secondary school context. Studies in the Second Language Learning and Teaching, 3(4), 523-550. https://doi.org/10.14746/ssllt.2013.3.4.5

Taipjutorus, W., Hansen, S., \& Brown, M. (2012). Investigating a relationship between learner control and self-efficacy in an online learning environment. Journal of Open, Flexible and Distance Learning, 16(1), 5669. https://www.learntechlib.org/p/147977/

Thompson, G., \& Woodman, K. (2019). Exploring Japanese high school English teachers' foreign language teacher efficacy beliefs. Asia-Pacific Journal of Teacher Education, 47(1), 48-65. https://doi.org/10.1080/1359866X.2018.1498062

Tschannen-Moran, M., \& Woolfolk Hoy, A. (2001). Teacher efficacy: Capturing an elusive construct. Teaching and Teacher Education, 17(7), 783-805. https://doi.org/10.1016/s0742-051x(01)00036-1 
Wallace, R. M. (2004). A framework for understanding teaching with the internet. American Education Research Journal, 41, 447-488.

https://doi.org/10.3102/00028312041002447

Zee, M., \& H. M. Y. Koomen. (2016). Teacher self-efficacy and its effects on classroom processes, student academic adjustment, and teacher well-being: a synthesis of 40 years of research. Review of Educational Research, 86(4), 981-1015. https://doi.org/10.3102/0034654315626801 


\section{APPENDIX}

\section{Online English Teaching Questionnaire}

Please indicate the nature of your online classes

$\square$ I provide students with videos

$\square$ I provide students with slides

$\square$ I provide students with readings

$\square$ I ask students to submit assignments

$\square$ I provide real time (synchronous) sessions using platforms such as Zoom, MS

Teams, Webex

$\square$ Other (Please specify)

\section{Part 1 Background Information}

1. What is your gender? Male Female Other

2. What is your age group? $\square$ under $25 \square 25-29 \square$ 30-39 $\square$ 40-49 $\square$ 50-59 $\square 60+$

3 . What is the highest level of formal education that you have completed?

$\square$ Bachelor degree $\square$ Master degree $\square$ Doctoral degree

4. How long have you been working as a teacher?

5 . How long have you been teaching online real time (synchronous) courses?

6. Roughly how many hours of online teaching workshops (seminars) have you taken before you started teaching online this year?

\section{Part 2 About Teaching Online}

Please indicate how much you agree or disagree with statements using the scale below:

1 - Strongly disagree

2 - Disagree

3 - Slightly disagree

4 - Slightly agree

5 - Agree

6 - Strongly agree

\section{Online pedagogical self-efficacy}

1. I can teach online even though I cannot provide face to face support.

1b. Please give reasons for this answer.

2. I can lead students on different learning tasks online.

3. I can develop students' language proficiency online.

4. I can motivate students online who show a low interest in language learning.

5. I can coordinate students' collaboration online.

6. I can motivate students online to do homework.

7. I can provide individual instruction to cater for students' individual needs online.

8. I can use summative (end-point) assessments to evaluate student learning online.

9. I can use formative (in-progress) assessments to evaluate student learning online. 
10. I can develop creative ways to teach online.

\section{Online technological self-efficacy}

11. I can use an online technology platform (e.g. Blackboard, Google Classroom Moodle, MS Teams, Zoom) for teaching.

12. I can help students when they have difficulty with devices (e.g. computers, tablets, smartphones).

13. I can use an online technology platform (e.g. Blackboard, Google Classroom Moodle, MS Teams, Zoom) to motivate students to participate.

14. I can use an online technology platform (e.g. Blackboard, Google Classroom Moodle, MS Teams, Zoom) to mentor students.

15. I can use an online technology platform (e.g. Blackboard, Google Classroom Moodle, MS Teams, Zoom) to conduct evaluations.

16. I can use software (e.g. spreadsheets, electronic portfolios) to manage student performance data.

17. I can find additional technological tools (e.g. apps, platforms) to support my teaching online.

\section{Online communicative language teaching self-efficacy}

1. I can manage group work activities online.

2. I can manage pair work activities online.

3. I can organize meaning-focused activities online (i.e. not focusing on linguistic forms).

4. I can organize task-based learning activities online (e.g. decision-making group work, information-gap task).

5. I can give corrective feedback to students online (e.g. correcting linguistic forms).

6. I can evaluate performance-based assessments online (e.g. oral presentation).

\section{Online self-management efficacy}

24. I can manage my workload when teaching online.

25. I can find help when I have difficulties teaching online.

26. I can find teacher development resources to improve my online teaching ability.

27. I can balance the demands of teaching and research when teaching online.

28. I can balance the demands of teaching and personal life when teaching online

29. I can allocate enough time to give individual feedback to students online.

Do you have any comments and/or questions? 